\section{Buletin Peternakan Tropis}

Bulletin of Tropical Animal Science

Doi: https://doi.org/10.31186/bpt.2.2.112-117
Bul. Pet. Trop. 2(2): 112-117, 2021

e-ISSN: $2722-0788$

p-ISSN: 2722-1733

\title{
Performa Anak Kambing Anglo Nubian Prasapih yang Diberi Susu Pengganti
}

\section{(Performance of Preweaning Anglo Nubian Lamb Feed with Milk Replacer)}

Tris Akbarillah ${ }^{1}$, Hidayat ${ }^{1 *}$, dan Alfeth June Tri Pratika ${ }^{2}$

1 Dosen Jurusan Peternakan, Fakultas Pertanian, Universitas Bengkulu

${ }^{2}$ Mahasiswa Jurusan Peternakan, Fakultas Pertanian, Universitas Bengkulu

* Penulis Korespondensi : hidayat@unib.ac.id

Dikirim (received): 13 Oktober 2021; dinyatakan diterima (accepted): 31 Oktober 2021; terbit (published): 15 November 2021. Artikel ini dipublikasi secara daring pada https://ejournal.unib.ac.id/index.php/buletin_pt/index

\section{ABSTRACT}

The objectives of this research were to evaluate the performance of Anglo Nubian lamb fed milk replacement and solid feeds. Twelve Anglo Nubian lambs were distributed in 3 treatments. Three treatments, goat milk and solid feeds (P1), cow milk and solid feeds (P2), and mixed of waste (discarded) industrial milk (50\%) and goat milk (50\%) and solid feeds (P3), were applied in Completely Randomized Design. The solid feeds were Indigofera leaves and solid waste of tofu industry. The observation of this research was 8 weeks. Variables measured were the average of feed consumption, and weight gain of lamb, additional length of lamb, height of lamb, and chest size. The average gain were $4.31-6.02 \mathrm{~kg} / \mathrm{head}$, length of lamb were $13.25-14.75 \mathrm{~cm} /$ head, height of lamb were $8.25-9.75 \mathrm{~cm} / \mathrm{head}$, and chest size were $8,50-12,50 \mathrm{~cm} /$ head. It was concluded that the use of cows milk and the waste (discarded) industrial milk could be applied to replace goat milk in raising Anglo Nubian lamb.

Key words: performance, Anglo Nubian goat, milk replacer

\section{ABSTRAK}

Penelitian ini bertujuan untuk mengevaluasi performa anak kambing Anglo Nubian yang diberi susu pengganti. Penelitian ini menggunakan rancangan acak lengkap (RAL) 3 perlakuan dan 4 ulangan. Setiap ulangan terdiri 4 ekor anak kambing Anglo Nubian. Formulasi setiap perlakuan yaitu P1 anak kambing diberi susu kambing murni dan pakan padati, P2 anak kambing diberikan susu sapi murni dan pakan padat, P3 anak kambing diberi susu campuran formulasi $50 \%$ susu afkir dan $50 \%$ susu kambing murni dan pakan padat. Pakan padat berupa hijauan Indigofera dan ampas tahu.Penelitian berlangsung selama 8 minggu. Variabel yang diamati yaitu konsumsi susu, konsumsi hijauan dan konsentrat, pertambahan berat badan, pertambahan panjang badan ternak, pertambahan tinggi badan ternak dan pertambahan lingkar dada ternak. Hasil penelitian diperoleh nilai rata-rata pertambahan berat badan berkisar 4,31$6,02 \mathrm{~kg} / \mathrm{ekor}$, pertambahan panjang badan ternak berkisar 13,25-14,75 cm/ekor, pertambahan tinggi badan ternak berkisar 8,25-9,75 cm/ekor dan pertambahan lingkar dada ternak berkisar 8,50-12,50 $\mathrm{cm} /$ ekor. Dari hasil penelitian dapat disimpulkan bahwa performa anak kambing Anglo Nubian pra sapih yang diberi susu pengganti sama dengan yang diberi susu induk.

Kata kunci: Performa, Kambing Anglo Nubian, Susu pengganti 


\section{PENDAHULUAN}

Tujuan usaha ternak kambing perah adalah menjual kelebihan produksi susu setelah mencukupi kebutuhan anaknya. Namun nilai jual susu kambing yang lebih tinggi dibanding susu sapi mendorong susu tersebut untuk dijual dan anak kambing pra sapih akan diberikan susu pengganti yang nilainya lebih murah.

Produksi susu kambing Anglo Nubian di Filipina rata-rata sebesar 1,38 liter/hari dengan masa laktasi 191,54 hari (Bondoc et al, 2018) lebih banyak dibandingkan dengan kambing Peranakan Ettawa yang memproduksi susu antara 1,2 -1,3 kg/hari (Marwah et al, 2010), dengan kandungan protein kasar 4,6-6,1 \% dan lemak 4,05-5,84 \% (Utari et al, 2012). Susu sapi murni dilaporkan dapat digunakan sebagai pengganti susu induk tanpa memberikan dampak negatif terhadap performa anak kambing. Penggunaan susu pengganti komersial juga telah dicobakan pada anak kambing pra sapih, pertambahan bobot hidupnya lebih rendah dari pada ternak yang disusui induknya (Chaniago dan Hastono, 2001). Dibandingkan susu kambing, harga susu sapi lebih murah. Susu sapi mengandung protein 2,53-2,69\% dan lemak 3,28-3,51\% (Suhendra et al, 2015). Selain susu sapi, beredarnya susu pakan ternak di pasaran, yang merupakan susu bubuk expired (afkir) dari pabrik susu, sering dimanfaatkan sebagai susu pengganti induk. Harga susu afkir ini lebih murah dibandingkan dengan susu sapi. Susu bubuk afkir mengandung protein 25,8\%, lemak $0,9 \%$ dan laktosa 4,6\% (Widodo, 2002). Selain susu, anak kambing yang sedang tumbuh memerlukan pakan padat untuk mencukupi kebutuhan potensi tumbuh kembangnya. Indigofera (Indigofera sp.) adalah leguminosa yang disukai kambing. Palatabilitasnya dilaporkan setara dengan Lamtoro (Leucaena leucocephala). Kandungan protein kasar (PK) hijauan Indigofera 24, 17\% (Sirait et al., 2012). Ampas tahu sering digunakan sebagai pakan tambahan (konsentrat)pada ternak kambing. Ampas tahu merupakan pakan konsentrat yang mengandung protein sebesar protein kasar (PK) 23,03\% (Dwiyana et al, 2021). Indigofera dan ampas tahu diharapkan dapat mencukupi kebutuhan tumbuh kembang anak kambing Anglo Nubian.

Berdasarkan uraian tersebut dilakukan evaluasi terhadap performa anak kambing Anglo Nubian pra sapih yang diberikan susu pengganti.

\section{BAHAN DAN METODE}

Waktu dan Tempat

Penelitian ini dilaksanakan pada tanggal 29 September sampai 24 November 2018 Penelitian ini berlangsung di Commercial Zone and Animal Laboratory (CZAL) Jurusan Peternakan Fakultas Pertanian Universitas Bengkulu.

\section{Alat dan Bahan}

Alat yang digunakan adalah timbangan pakan, timbangan gantung, ember, dot susu, sabit, plastik, karung, pita ukur, tongkat ukur, tali, alat tulis.

Bahan yang digunakan yaitu anak kambing Anglo Nubian sebanyak 12 ekor dengan umur yang relatif sama 1,5 bulan, pakan hijauan (Indigofera), ampas tahu, susu bubuk afkir, susu kambing Anglo Nubian dan susu sapi murni. Susu bubuk afkir dilarutkan dengan air dengan perbandingan $200 \mathrm{~g}$ susu bubuk afkir menjadi 1 liter larutan susu bubuk afkir.

\section{Rancangan Percobaan}

Dua belas anak kambing AngloNubian umur 1,5 bulan didistribusikan ke dalam 12 kandang individu ukuran $80 \mathrm{~cm} \times 60 \mathrm{~cm}$ yang dilengkapi tempat pakan dan minum. Penelitian ini menggunakan rancangan acak lengkap dengan 3 perlakuan dan 4 ulangan. Sedangkan ketiga perlakuan adalah sebagai berikut :

$$
\begin{aligned}
\mathrm{P} 1= & \text { Susu induk } 100 \%(700 \mathrm{ml})+\text { pakan } \\
& \text { hijauan dan konsentrat (ad libitum })
\end{aligned}
$$


P2 = Susu sapi murni $100 \%(700 \mathrm{ml})+$ pakan hijauan dan konsentrat (ad libitum)

P3 = Susu bubuk afkir 50\% + Susu Induk 50\% (700 ml) + hijauan dan konsentrat ( ad libitum)

\section{Pelaksanaan Penelitian}

\section{Pengukuran}

Penimbangan dan pengukuran tinggi badan, panjang badan, dan lingkar dada ternak dilakukan sebelum perlakuan dan diulang setiap minggu sampai akhir penelitian.

\section{Pemberian susu}

Masing-masing anak kambing diberi susu sebanyak $700 \mathrm{ml}$ per hari yang diberikan 2 kali pagi dan sore, sesuai perlakuan. hari berikutnya. Hijauan dan ampas tahu diambil sampel untuk dilakukan analisa bahan kering, bahan organik dan protein kasar.

\section{Variabel yang diamati}

Variabel yang diamati meliputi konsumsi pakan, konsumsi susu, lingkar dada, lingkar dada, tinggi badan, panjang badan, pertambahan berat badan

\section{Analisis Data}

Data yang diperoleh dianalisis dengan menggunakan sidik ragam (ANOVA). Apabila hasil analisis dari penelitian ini berpengaruh nyata $(P<0,05)$ maka dilanjutkan dengan $U j i$ Duncan's Multiple Range Test (DMRT).

Tabel 1. Konsumsi BK, BO, dan PK pakan padat pada anak kambing Anglo Nubian pra sapih selama penelitian (8 minggu)

\begin{tabular}{llcccc}
\hline Pakan & & P1 & P2 & P3 & P \\
\hline Hijauan $(\mathrm{kg})$ & Bahan Kering & 4,12 & 4,09 & 4,03 & 0,74 \\
& BahanOrganik & 3,78 & 3,75 & 3,70 & 0,74 \\
& Protein Kasar & 1,15 & 1,14 & 1,12 & 0,74 \\
\hline \multirow{2}{*}{ Konsentrat (kg) } & Bahan Kering & 3,69 & 3,76 & 3,75 & 0,98 \\
& BahanOrganik & 3,53 & 3,52 & 3,62 & 0,95 \\
& Protein Kasar & 1,02 & 1,09 & 0,97 & 0,54 \\
\hline Total $(\mathbf{k g})$ & Bahan Kering & 7,81 & 7,85 & 7,78 & 0,94 \\
& BahanOrganik & 7,31 & 7,27 & 7,32 & 0,99 \\
& Protein Kasar & 2,17 & 2,23 & 2,09 & 0,56 \\
\hline
\end{tabular}

\section{Pemberian Padatan}

Pemberian pakan hijauan (Indigofera) segar sebanyak $300 \mathrm{~g} / \mathrm{ekor} / \mathrm{hari}$ pada minggu pertama dan kedua pada minggu selanjutnya ditambah sebanyak 50 gram di minggu berikutnya. Pemberian hijauan dilakukan sekali (pagi hari) pada 2 minggu pertama, kemudian pada minggu ke-3 dan seterusnya, pakan hijauan diberikan 2 kali sehari (pagi dan sore). Pemberian hijauan setelah diberikan ampas tahu (konsentrat). Pemberian pakan konsentrat (ampas tahu) diberikan 200 g/ekor/hari dan pada minggu pertama dan ditambah 50 gram setiap minggunya. Konsentrat diberikan 1 kali sehari selama penelitian. Sisa pakan padatan di timbang di

\section{HASIL DAN PEMBAHASAN}

Konsumsi Bahan Kering( BK), Bahan Organik (BO) dan Protein Kasar (PK) Pakan Hijauan, Konsentrat dan Pakan Total

Ternak yang mendapatkan perlakuan baik P1 (susu induk kambing), P2 (susu sapi) dan P3 (campuran susu induk dan susu afkir) sebanyak $700 \mathrm{ml}$ per hari terkonsumsi habis. Menurut Supriyati (2012) anak kambing Peranakan Etawah mampu mengkonsumsi 600 sampai $1200 \mathrm{ml}$ susu sapi, tergantung umur, yang mana hal ini berhubungan dengan masa pertumbuhannya, khususnya perubahan anatomi dan fisiologi pada saluran pencernaan. Sehubungan dengan nutrisi yang terkonsumsi dari susu perlakuan, kebutuhan nutrisi anak kambing untuk tumbuh akan 
didapatkan dari pakan padatan yang tersedia lebih. Kebutuhan nutrisi untuk tumbuh kembang anak kambing dapat dicukupi dari pakan padatan.

Konsumsi pakan padat, berupa BK, BO, dan PK, baik yang berasal dari hijauan dan konsentrat serta total pada anak kambing Anglo Nubian pra-sapih selama penelitian (8 minggu) tercantum pada Tabel 1.

Berdasarkan analisis variansi (anova), didapatkan hasil bahwa perlakuan penggunaan susu yang berbeda berpengaruh tidak nyata $(P>0,05)$ terhadap konsumsi hijauan dan konsentrat, baik terhadap konsumsi bahan kering (BK), bahan organik (BO), dan protein kasar (PK). Pakan padatan berupa hijauan (Indigofera) merupakan pakan yang disukai kambing (Simanihuruk dan Sirait, 2009), demikian juga dengan ampas tahu (Dwiyana et al., 2021). Rata-rata konsumsi total bahan kering 139,5 g/ekor/hari (P1), 140,2 g/eko/hari (P2) dan 138,9 g/ekor/hari (P3), yang terdiri dari Indigofera 73,6 g/ekor/hari (P1), 73,0 g/ekor/hari (P2), dan $72,0 \mathrm{~g}$ /ekor/hari, serta ampas tahu 65,9 g/ekor/hari (P1), 67,1 g/ekor/hari (P2), dan 67,0 g/ekor/hari. Dari Tabel 1 diatas dapat dilihat bahwa imbangan konsumsi BK, jumlah pemberian yang sama yaitu sebanyak $700 \mathrm{ml} / \mathrm{ekor} / \mathrm{hari}$ direspon ternak dengan mengkonsumsi pakan padatan yang berbeda tidak nyata, baik hijauan maupun konsentrat. Hal ini karena jumlah konsumsi pakan oleh ruminansia dipengaruhi antara lain umur ternak (perkembangan dan daya tampung saluran pencernaan) dan komposisi kimia pakan (Parakkasi, 1995). Indigofera merupakan hijauan pakan yang disukai kambing (Sirait et al., 2012), demikian juga dengan ampas tahu (Dwiyana et al., 2021). Konsumsi pakan padat berupa Indigofera dan ampas tahu diantara 3 perlakuan susu pengganti yang berbeda tidak nyata $(P>0,05)$ menunjukkan bahwa pemberian susu pengganti yang berbeda tidak berpengaruh. Hal ini lebih barangkali disebabkan kontrol kenyang secara fisik, dimana volume susu pengganti yang diberikan $700 \mathrm{ml} /$ ekor/hari untuk masing-masing perlakuan.

\section{Pertambahan Berat Badan, Panjang Badan} Lingkar Dada, dan Tinggi Ternak

Pertambahan berat badan (BB), panjang badan (PB), lingkar dada (LD) dan tinggi gumba (TG) adalah parameter-parameter yang digunakan untuk menilai respon ternak

Tabel 2. Tinggi gumba, panjang badan, lingkar dada, dan berat badan kambing selama penelitian ( 8 minggu)

\begin{tabular}{llcccc}
\hline Variabel & & P1 & P2 & P3 & P \\
\hline Tinggi Gumba & Awal & 47,75 & 49,50 & 49,25 & 0,61 \\
(cm) & Akhir & 57,50 & 59,50 & 57,50 & 0,62 \\
& Pertambahan & 9,75 & 10,00 & 8,25 & 0,42 \\
\hline Panjang Badan & Awal & 43,75 & 43,25 & 44,50 & 0,81 \\
(cm) & Akhir & 58,50 & 58,00 & 57,75 & 0,95 \\
& Pertambahan & 14,75 & 14,75 & 13,25 & 0,61 \\
\hline Lingkar Dada & Awal & 48,25 & 49,00 & 50,50 & 0,33 \\
(cm) & Akhir & 60,75 & 59,50 & 59,00 & 0,67 \\
& Pertambahan & 12,50 & 10,50 & 8,50 & 0,10 \\
\hline Berat Badan & Awal & 8,94 & 8,90 & 9,39 & 0,71 \\
(kg) & Akhir & 14,96 & 14,42 & 13,70 & 0,65 \\
& Pertambahan & 6,02 & 5,52 & 4,31 & 0,27 \\
\hline
\end{tabular}

Indigofera dikonsumsi 52,75\% (P1), 52,10\% (P2), dan $51,80 \%$ (P3) dari total pakan padat. Terlihat disini bahwa pemberian susu perlakuan yang berbeda kualitasnya, namun terhadap kualitas pakan. Pakan hijauan leguminosa Indigofera dan konsentrat berupa ampas tahu serta susu pengganti pada anak kambing berdampak pada pertumbuhan anak 
kambing. Pertumbuhan juga didefinisikan sebagai perubahan ukuran yang meliputi perubahan berat hidup, bentuk dimensi linear dan komposisi tubuh termasuk perubahan organ-organ dan jaringan tersebut (Soeparno, 1994). Pertumbuhan anak kambing yang diberikan susu pengganti yang berbeda tersaji pada Tabel 2.

Tabel 2. menunjukkan bahwa anak kambing yang digunakan memiliki rata-rata TG, PB, LD, dan BB yang berbeda tidak nyata $(P>0,05)$, yaitu pada kisaran $47,75-49,5 \mathrm{~cm}$ (TG), 43,25-44,5 cm (PB), 48,25-50,5 cm (LD) dan 8,90-9,39 kg (BB) pada awal penelitian.

Hasil rata-rata perlakuan menunjukkan bahwa perlakuan berpengaruh tidak nyata $(P>0,05)$ terhadap TG, PB, LD, dan BB di akhir penelitian, demikian juga dengan pertambahan TG, PB, LD, dan BB anak kambing.

Rata-rata pertambahan tinggi badan menghasilkan perbedaan yang tidak nyata $(P>0,05)$ pada semua perlakuan penggunaan susu dari induk, sapi dan campuran, berturut turut adalah $9,75 \mathrm{~cm}$, $10,00 \mathrm{~cm}$, dan $8,25 \mathrm{~cm}$. Namun demikian, susu campuran (P3) memiliki nilai rata-rata pertambahan tinggi badan cenderung rendah.

Rata-rata pertambahan panjang badan selama 8 minggu adalah P1 sebesar $14,75 \mathrm{~cm}$, P2 sebesar 14,75 cm dan P3 sebesar 13,25 cm $(P>0,05)$. Berkaitan dengan PBB menunjukkan bahwa terdapat hubungan bobot badan dengan panjang badan yang sesuai. $\mathrm{P} 3$ dengan total rata-rata penambahan bobot badan selama 8 minggu sebesar $4,31 \mathrm{~kg} / \mathrm{ekor} / \mathrm{minggu}$ atau $0,08 \mathrm{~kg} / \mathrm{ekor} / \mathrm{hari}$ memiliki nilai pengukuran panjang badan cenderung paling rendah dibanding dengan $\mathrm{P} 1$ dan $\mathrm{P} 2$.

Nilai rata-rata pertambahan lingkar dada berkisar 0,15-0,22 cm/ekor/hari. Lingkar dada menggambarkan pertumbuhan pada ternak yang masih muda lebih memfokuskan pertumbuhan pada tulang.
Nilai rataan PBB selama penelitian pada perlakuan P1 6,02 kg/ekor, P2 5,52 kg/ekor dan P3 4,31 kg/ekor atau 107,5 g/ekor/hari, 98,6 g/e/hari, dan 77,0 g/e/hari. Hal ini dikarenakan konsumsi BK total dan PK total (Tabel 1) berbeda tidak nyata baik konsumsi pakan hijauan maupun konsentratnya. Dari keseluruhan hasil PBB harian terlihat masih belum memenuhi angka pertambahan bobot badan menurut Sarwono (2007) yang menyatakan bahwa PBBH kambing yang digemukkan secara intensif bisa mencapai 100-150 g/ekor/hari dengan rata-rata 120 g/ekor/hari atau 700-1.050 g dengan rata-rata 840 g per minggu. Seperti disampaikan oleh Maharani (2017) yang menyatakan bahwa laju pertumbuhan ternak mengikuti kurva sigmodial.

Dari kedua Tabel diatas dapat diekspresikan bahwa rata-rata konsumsi BK pakan padat dibanding dengan berat badan anak kambing pada perlakuan P1 sebesar 1,16\%, P2 sebesar 1,20\%, dan P3 sebesar 1,2 \%. Sebagai ruminan muda terlihat konsumsi BK pakan padatan masih relatif rendah, dikarenakan kapasitas retikulorumen yang masih belum berkembang. Kemampuan konsumsi BK ternak ruminan dipengaruhi oleh umur ternak dan perkembangan saluran pencernaannya. Seperti disampaikan Dhuhitta et al (2014) bahwa kambing muda mengkonsumsi bahan kering lebih sedikit dibandingkan kambing dewasa.

\section{KESIMPULAN}

Penggunaan susu sapi murni dan susu bubuk afkir yang dicampur dengan susu induk kambing dapat menggantikan keseluruhan susu induk atau sebagian dan tidak memberikan efek negatif pada pertumbuhan baik pertambahan berat badan (PBB), pertambahan panjang badan, pertambahan tinggi badan dan pertambahan lingkar dada anak kambing Anglo Nubian yang diberi pakan padatan Indigofera dan ampas tahu. 


\section{DAFTAR PUSTAKA}

Bondoc, O. L., N. A. Del Rosario, L. L. Manalili and E. M. Cruz. Genetic and Phenotypic Trends in Milk Production Traits of Anglo Nubian Goats From Selected Farms in the Philippines. Philipp J Vet Anim Sci 201844 (2): $139-150$

Chaniago, T. D. \& Hastono. 2001. Pre-weaning growth of Etawah Crossed kid fed with replacement milk. Pros. Seminar Nasional Teknologi Peternakan dan Veteriner. Bogor, 17-18 September 2001, Puslitbang Peternakan, Bogor. Pp. 241-246.

Dhuhitta, A. M., S. Dartosukarno dan A. Purnomoadi. 2014. Pengaruh Jumlah Pakan yang Berbeda Terhadap Kondisi Fisiologi Kambing Kacang. Animal Agriculture Journal 3(4): 569-574

Dwiyana, T., T.Akbarillah, dan Hidayat. 2021.Pengaruh Penggunaan Ampas Kelapa (Cocos nucifera L.) dalam Konsentrat dengan Level Berbeda terhadap Produksi Susu Kambing Nubian. Jurnal Sain Peternakan Indonesia. Vol. 16(1) 8-16

Maharani, D., A.H.K. Amrullah., D.T. Widayati., Sumadi., A. Fathoni., and M. Khusnudin. 2017. Predicting the Age and Weight at Puberty of Ongole Grade Cattle using Nonlinear Mathematical Model in Kebumen Farmer Association. J. Indonesian. Trop. Anim. Agric. 42(4), 233239.

Marwah, M.P., Y.Y. Suranindyah, dan T. W. Murti. 2010. Produksi dan komposisi susu kambing Peranakan Ettawa yang diberi suplemen daun katu (Sauropus androgynus (L) Merr) pada awal masa laktasi. Buletin Peternakan Vol. 34(2): 94-102

Parakkasi, A., 1995. Ilmu Nutrisi Ruminansia Pedaging. Departemen IImu Makanan
Ternak, Fakultas Peternakan, Institut Pertanian Bogor: Bogor.

Sarwono, B. 2007. Beternak Kambing Unggul.Penebar Swadaya, Jakarta.

Simanihuruk, K dan J. Sirait. 2009. Pemanfaatan Leguminosa Pohon Indigofera sp. Sebagai Pakan Basal Kambing Boerka Fase Pertumbuhan. Prosiding Seminar Nasional Teknologi Peternakan dan Veteriner: Inovasi teknologi mendukung pengembangan agribisnis peternakan ramah lingkungan. Bogor. 1112 Nop 2008.

Sirait, J., K. Simanihuruk dan R Hutasoit. 2012. Potensi Indigofera sp. Sebagai Pakan Kambing: Produksi, Nilai Nutrisi dan Palatabilitas. Pastura Vol. 1 No. 2 : $56-60$

Soeparno. 1994, Ilmu dan Teknologi Daging. Gadjah Mada University Press, Yogyakarta. Suhendra, D., G.T. Anggiati, S. Sarah, A.F. Nasrullah, A. Thimoty dan DW. C. Utama. 2015. Tampilan kualitas susu sapi perah akibat imbangan konsentrat dan hijauan yang berbeda. Jurnal IImu-IImu Peternakan 25 (1): $42-46$

Supriyati.2021. Pertumbuhan Kambing Peranakan Etawah Prasapih, yang Diberi Susu Pengganti. JITV Vol. 17 (2) 142-151 Utari, F. D., B. W. H. E. Prasetiyono dan A. Muktiani. (2012). Kualitas Susu Kambing Perah Peranakan Etawa yang Diberi Suplementasi Protein Terproteksi dalam Wafer Pakan Komplit Berbasis Limbah Agroindustri. Animal Agriculture Journal, Vol. 1. No. 1, p 427-441

Widodo, W. 2002. Bioteknologi Fermentasi Susu. Pusat Pengembangan Bioteknologi. Universitas Muhammadiyah. Malang. 